\title{
Ultrasonographic diagnosis and management of fetal abnormality in the mare in late pregnancy
}

\author{
A.J. McGladdery \\ Rossdale and Partners, Beaufort Cottage Stables, High Street, Newmarket, UK
}

\begin{abstract}
Summary
Pregnant mares suspected of having a complication can be examined by transabdominal ultrasonography to determine the state of fetal well-being. Reasons include premature mammary development and lactation, vulval discharge, severe maternal disease, marked abdominal enlargement and prolonged gestation. Useful measurements include fetal aortic diameter, fetal heart rate and activity, fetal fluid depth and consistency, utero-placental thickness and contact, fetal position and presentation and the presence of fetal breathing movements. The combined utero-placental thickness can also be measured transrectally. Combining these parameters into a biophysical profile may predict with greater accuracy the final fetal outcome. Any inaccuracy may be related to problems that develop during delivery such as dystocia and premature placental separation which were not present previously. In one large series of 122 cases, $61 \%$ of fetal scans were normal of these supposedly normal pregnancies $79 \%$ delivered a normal foal, $39 \%$ of scans were abnormal of these $19 \%$ subsequently delivered a normal foal. Once the state of fetal well-being has been assessed management is directed at treating the maternal disease appropriately, combined with specific treatments including the use of antibiotics in placentitis and progesterone supplementation. Fetal adrenocortical maturation is essential to new born foal viability. Because it occurs at the very end of gestation therapy should be aimed at maintaining a stable 'in utero' environment capable of supporting the fetus until this has been achieved. However, due to suspected impending fetal death premature delivery of the fetus may be necessary. Increasing the speed of fetal adrenocortical maturation by intra-fetal administration of ACTH, in selected cases, particularly where maternal death is imminent and full term is distant should be considered carefully as the technique is not without risk.
\end{abstract}

Keywords: $\quad$ ultrasonography, horse, fetal assessment, pregnancy, fetal maturation

\section{Ultrasonographische Diagnostik und Behandlung fötaler Fehlformationen bei Stuten in der späten Graviditätsphase}

Bei Verdacht auf einen komplikativen Verlauf der Trächtigkeit kann der Vitalitätszustand des Föten durch transabdominale Ultrasonographie bestimmt werden. Indikationen für diese Untersuchungen sind vorzeitige Euteranbildung und Laktation, Genitalausfluss, schwerwiegende Erkrankung der Mutterstute, auffälliger Bauchumfang und verlängerte Trächtigkeit. Brauchbare Untersuchungsverfahren schliessen den fötalen Aortendurchmesser, fötale Herzfrequenz und Aktivität, Ausmass und Konsistenz der Fruchtwässer, Dicke der Utero-Plazentaschicht und deren Kontakt, die fetale Stellung und Lage und das Vorhandensein fötaler Atmungsintentionen ein. Die kombinierte utero-plazentale Schichtdicke kann ebenfalls über die transrektale Ultrasonographie gemessen werden. Die Kombination dieser Parameter in einem biophysikalischen Profil kann zu einer größeren prognostischen Genauigkeit bezüglich des weiteren Fortgangs der Trächtigkeit und der Vitalitäts-Chancen des Fohlens führen. Fehlprognosen nach Anwendung eines solchen Untersuchungsprofils dürften auf Probleme zurückzuführen sein, die sich erst während des Geburtsablaufs ergeben wie z.B. Dystokien oder vorzeitige Plazentaablösung, die vorher nicht erkannt werden können.

In einer großen Serie von 122 Fällen fötaler Untersuchungen wurden $61 \%$ als normal eingestuft, von denen $79 \%$ normale Fohlen geboren wurden. In 39\% der untersuchten Leibesfrüchte wurde eine abnormale Fruchtanlage diagnostiziert, von denen in 19\% der Fälle ein normales Fohlen geboren wurde. Sobald der fötale Vitalitätsstatus festgestellt ist, richtet sich die Behandlung möglichst kausativ gegen die mütterliche Erkrankung in Kombination mit spezifischer Therapie, die die Applikation von Antibiotika in Fällen von Plazentitis und die Supplementierung von Progestagenen beinhaltet. Die fetale, adrenocortikal gesteuerte Ausreifung ist essentiell wichtig für die Vitalität des Neugeborenen. Da dies in den letzten Phasen der Gravidität erfolgt, sollte eine Therapie die Aufrechterhaltung eines stabilen endouterinen Milieus, das zur Erhaltung des Fötus' in der Lage ist, zum Ziel haben. Jedoch kann bei unmittelbar zu erwartendem Fruchttod die vorzeitige Geburt des Föten erforderlich sein. Die Beschleunigung der fötalen Reifung durch intrafötale Applikation von ACTH in besonderen Fällen, z.B. bei bevorstehendem mütterlichem Tod und noch nicht erreichtem Abfohltermin bedarf sorgfältiger Abwägung, da diese Behandlungstechnik nicht ohne Risiko ist.

Schlüsselwörter Ultrasonographie, Pferd, Fetusuntersuchung und -bewertung, Trächtigkeit, fetale Reifung

\section{Introduction}

Ultrasonographic examination is the most useful technique for assessing fetal well-being in mares that develop complications in late pregnancy (Adams-Brendemuehl and Pipers, 1987; McGladdery, 1998). Although, in late pregnancy transcutaneous or transabdominal examination provides the best visualisation of the fetus, transrectal examination will allow more detailed examination of the head and neck of the fetus and placenta at the cervical pole. Indications for assessment of fetal well being include premature mammary development and lactation, vaginal discharge, excessive abdominal enlargement, a previous maternal history of dystocia and/or premature placental separation, a previous history of a foal suffering from prematurity or sepsis, severe maternal illness (eg. fever/endotoxaemia) or disease cau- 
sing marked disability or debilitation (eg. severe malnutrition, chronic severe lameness/laminitis or severe neurological disease), abdominal pain (particularly of reproductive origin) and prolonged gestation. Following assessment of the fetus, a management plan can be formulated, in conjunction with any maternal therapy, for the best care of the pregnancy until full term. Because the major organs of the equine fetus are required to undergo critical maturational processes during the last days of pregnancy, fetal survival at less than 295-300 days of gestation is rare. Even after this time, delivery of a mature fetus is not certain, and problems of dysmaturity are frequently encountered. However, fetoplacental stress, in some circumstances (eg. placentitis), may cause sufficient maturity of the fetal adrenal cortex to occur that increased viability of the foal is possible even at early gestational ages. For this reason, most management regimes are designed to enhance, if possible, fetal viability in utero. However, if imminent fetal demise is suspected, then induction of parturition and delivery of the foal, may become essential.

\section{Diagnosis}

Ultrasonographic examination of the fetus may be performed using either a linear or sector transducer. Normally a 3.5 $\mathrm{MHz}$ or lower frequency transducer is used for general surveying of the fetus and placenta with more detailed examinations made using a $5 \mathrm{MHz}$ or $7.5 \mathrm{MHz}$ transducer. Because sedative drugs will affect fetal activity and fetal heart rate and therefore limit the accuracy of fetal assessment, sedation of the mare should be avoided. During a routine fetal ultrasound examination, the mare's ventral abdomen should be systematically examined from her sternum to her mammary gland and on either side of midline to the level of the flank fold. In late gestation the fetus will, in nearly all cases, be in anterior presentation either in dorsal or dorsolateral recumbency. The fetal thorax is usually the most easily identified structure, the fetal heart can be readily identified contracting in the cranial thorax with the major blood vessels passing caudally, the aorta lying next to the spinal vertebrae. The diaphragm can be recognised separating the abdominal and thoracic cavities and fetal breathing movements may be noted. In the fetal abdomen, the fluid filled (anechoic) stomach, kidneys and liver are all easily identified. The umbilical cord $(2$ umbilical arteries, umbilical vein, urachus), can be seen floating within the fetal fluids. The amnion forms a brightly, echogenic membrane that divides the amniotic cavity from the allantoic cavity. The placenta can be recognised bordering the allantoic cavity, the uterus and placenta form a combined structure which is homogeneous in appearance and normally less than $2 \mathrm{~cm}$ in thickness.

Several different measurements of the fetus have been made during mid and late gestation with the aim of predicting fetal size relative to gestational age. The most consistently useful has proved to be aortic diameter (measured at the caudal border of the heart. Although, initial studies (Adams-
Brendemuehl and Pipers, 1987) of fetal aortic diameter did not find a strong correlation with neonatal foal weight and were not considered accurate in detecting small or impoverished fetuses. A more recent study (Reef et al., 1996) has found both the fetal aortic and thoracic diameter to be accurate in predicting the small fetus in a high risk pregnancy. Besides detecting the thickness of the combined uterus and placenta, areas of placental separation may also be noted. The fetal fluids are normally anechoic, however, the allantoic fluid in late gestation may contain numerous hyperechoic foci. During fetal distress, meconium diarrhoea may lead to an increased number and size of free floating particles within the amniotic fluid. This must be differentiated from the hippomane, which is an easily recognised oval, echogenic, concentric structure seen floating in the allantoic fluid. The depth of the fluid pool surrounding the fetus can be measured to assess the overall total volume of fetal fluid both amniotic and allantoic. Other measurements that are useful, include fetal heart rate (either measured directly by counting the number of fetal heartbeats over a defined period of time or alternatively, the R-R interval can be calculated by $\mathrm{M}$ mode scanning of the fetal heart). Numerous workers have documented the decreasing fetal heart rate that occurs with increasing gestational age related to increasing parasympathetic tone in the developing fetus. Transient fetal heart rate accelerations are associated with fetal movement and activity in the normally developing fetus. Assessment of fetal activity is also useful and during a routine scan of 20-30 minutes duration it is unusual to see periods of more than a few minutes of fetal inactivity or fetal sleep. Limb, head and neck and rotational movements around the fetal body axis can be visualised. Two groups of workers (Adams-Brendemuehl and Pipers, 1987; Reef et al., 1995) have reported normal values for the late gestational fetus. Both have developed a biophysical profile to detect fetal abnormality based on a scoring system involving several different measurements (Reef et al., 1996).

The following ultrasound findings have been associated with a suspected or proven abnormality of the fetus. Fetal heart rates, either much higher or much lower than expected for fetal gestational age, were associated with abnormality. An inactive fetus with a resting heart rate of greater than 100 beats or a fetus with a heart rate of less than 50 beats was consistently associated with abnormality. Prolonged periods of fetal inactivity were consistently associated with abnormality. However, in a small number of cases, abrupt markedly excessive activity was also associated with abnormality. Besides fetal activity, fetal tone has also been assessed and when absent was associated with abnormality. Reef et al. (1996) consistently found that aortic diameter correlated well with foal weight in both normal and complicated pregnancies. Not all clinical workers have supported this finding. Reduced quantities, particularly of allantoic fluid were associated with abnormality, as was increased echogencity of the fetal fluids. Where abdominal enlargement occurs in late pregnancy, ultrasound examination may reveal fetal hydrops with excessive production of fetal fluid, either allantoic or amniotic in origin. In these cases, on rec- 
tal palpation, it is normally impossible to palpate the fetus. Transabdominal scan finds that the fetus is surrounded by a much larger volume of fluid than normal. In one case a fetus also had an omphalocele with herniated intestines, which were visible on ultrasound examination. As has been mentioned previously, examination of the uteroplacental unit may reveal thickening, focal increased echogencity associated with calcification and placental separation.

Measurement of the combined thickness of the uterus and placenta (CTUP) has recently been reported by transrectal measurement at the ventral aspect of the uterine body and near the cervical-placental junction (Troedsson et al., 1997). The normal CTUP is reported to be less than $7 \mathrm{~mm}$ before 300 days of gestation. Mares at risk of placental failure have CTUP's $>8 \mathrm{~mm}$ at 271-300 days and $>10 \mathrm{~mm}$ 301-330 days. The presence of fetal breathing movements is not associated with abnormality. Unfortunately, the presence of one abnormal measurement alone is not always accurate in indicating the probability of a poor fetal outcome. For this reason biophysical profiling has been used to predict fetal outcome. Reef et al. (1996) have developed a biophysical profile using the following variables, fetal heart rate, aortic diameter, fetal activity level, utero-placental thickness, uteroplacental contact and maximal fetal fluid depth. A score of 2 for normal and 0 for abnormal are assigned to each variable and the 6 variables are summed to give a biophysical profile score that ranges from 0 to 12 . If a fetus had a biophysical profile score that was less than or equal to 8 it was assured of a negative outcome. However, a maximal score was not an assurance of normality. In most cases, the reason for an abnormal outcome with a maximum biophysical profile score was associated with problems that developed during delivery including premature placental separation, dystocia and failure of the chorioallantois to rupture. In a large scale study by Reimer (1997) of 122 mares that had complicated pregnancies, $61 \%$ of pregnancies were considered to be normal following ultrasound examination (Biophysical profiling was not used). Of these, $79 \%$ were associated with a normal foal at delivery. $16 \%$ of foals resulting from pregnancies with a normal ultrasound examination were stillborn, died or were euthanised before 48 hours. Some of these cases were either associated with dystocia or caesarean section due to an ultimately fatal disease of the mare. The vast majority of mares with prolonged gestations had normal ultrasound examinations and a normal fetal outcome. In one case, in the author's experience, of a prolonged gestation associated with abnormal fetal outcome. The fetus was noted to be consistently inactive, on repeated ultrasound examination, with a bradycardia and absence of fetal heart rate variability. The fetus was eventually stillborn and found to be congenitally abnormal with anencephaly and an open defect in the cranium. In Reimer's survey, in 39\% of mare's fetal ultrasound examinations were considered to be abnormal. In these cases, abnormal findings included thickened placenta, echogenic retroplacental fluid and placental separation (subsequently found to be mucoid, purulent or haemorrhagic at parturition) both fetal hydrops and reduced quantities of allantoic/amniotic fluid, fetal death, breech presentation in late pregnancy, twin pregnancy, fetal ascites and omphalocele. Also, inappropriately low or elevated heart rates and cardiac arrhythmias were also noted. In two cases fetuses were noticed to have sudden bouts of abnormally, excessive activity characterised by apparently violent activity with periods of abrupt cessation. In both cases the foals died. In several cases inactivity was associated with a poor fetal outcome. However, one foal was found to be completely inactive on several ultrasound examinations, yet at delivery was normal. $19 \%$ of abnormal ultrasound examinations were associated with a normal foal. During fetal evaluation, peritonitis, haemoperitoneum and broad ligament haemorrhage were identified in three mares.

\section{Management}

Therapy for mares with complications in late pregnancy is directed primarily at appropriate treatment of the maternal disease. Mares with placentitis may be treated with systemic antimicrobials chosen depending on the antibiotic sensitivity of the organism cultured. Experimental evidence has so far indicated that, normally, only trimethoprim crosses the placenta to the fetal circulation however, in cases of placentitis inflammation of the chorioallantois may allow greater and more varied transfer of drugs. Although, a variety of maternal conditions particularly those associated with endotoxaemia may result in large increases in uterine prostaglandins capable of causing abortion there is no evidence that the use of Nonsteroidal drugs, which inhibit cycloxygenases, are able to prevent abortion. Similarly, the use of exogenous progesterone therapy (eg. altrenogest), which is widespread, may possibly cause increased uterine quiescence with reduced myometrial activity and increased cervical integrity. Some clinicians advocate the use of tocolytic drugs such as clenbuterol which relax the myometrium. Both progesterone and altrenogest do appear able to block the effect of cloprostenol induced abortion and this, effect on prostaglandins, is an important reason for their use in complicated pregnancies.

Regular reassessment of the complicated pregnancy as term approaches is helpful to allow preparation for delivery of a compromised foal. In some cases the possibility of speeding up fetal maturation to allow early delivery of a viable foal compared to that normally expected for the gestational age would be a great advantage. Studies in research ponies have shown that it is possible to advance gestation of a viable foal by direct fetal therapy. The author has experience of treating 3 clinical cases with fetal ACTH injections to induce precocious fetal adrenocortical maturation. The first case was a TB mare with severe, acute laminitis. Fetal injections of $1 \mathrm{mg}$ of depot ACTH were given via an ultrasound-guided technique at 309 days and daily from 337-339 days of gestation and delivery was induced at 341 days. Although, the foal did require some hospitalisation due to dysmaturity it did survive. The second case involved a TB mare with severe emaciation due to eosinophilic gra- 
nulomatous enteritis. Fetal injections were given at 368 and 370 days because of the mare's physical condition and lack of mammary development. Premature placental separation at 371-372 days resulted in fetal death during delivery. In the third case a TB mare with a septic tenosynovitis causing severe unilateral hindlimb lameness underwent fetal injections daily at 314-316 days of gestation and delivery by caesarian section at 331 days again resulted in a dysmature foal which although, it survived until 10 days of age was then finally euthanised due to a septic joint. In two of these cases premature delivery of a viable foal appeared improved due to fetal injection. However, the procedure is not without risk and abortions and placental lesions were associated with the fetal injections in some of the research ponies injected. In view of this, the use of this technique should be considered carefully and limited to cases where fetal maturation is essential because of the imminent demise of the mare.

\section{Literature}

Caroline S. Adams-Brendemuehl and F.S. Pipers (1987): Antepartum evaluations of the equine fetus. J. Reprod. Fert. Suppl. 35, 563-73.

A.J. McGladdery (1998): Fetal Ultrasonography. Equine Diagnostic Uitrasonography Edited by N.W. Rantanen and A.O. McKinnon, publisher, Williams and Wilkins, Baltimore, USA, 171-180.

Jennifer C. Ousey, P.D. Rossdale, F. E. Dudan and Abigail L. Fowden (1999): The effects of intra-fetal ACTH administration on the outcome of pregnancy in the mare. Reprod. Fert.Dev. 10, (4).
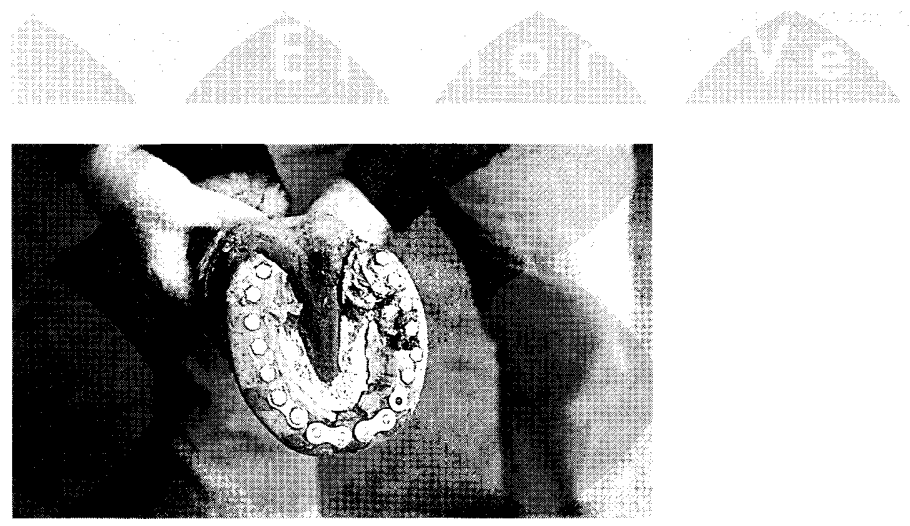

Das Einhorn-Verbundhufeisen ist eine Beschichtung der unteren Hornwand und der äußeren Hufsohle mit einer 1-15 mm dicken Kunsthornschicht (Methyl Methacrylat), in die Metallsegmente eingebettet sind.

In seinem Gutachten über das Verbundhufeisen schreibt Prof. Budras, FU Berlin: "Es wirkt wie ein Außenskelett, schützend auf die natürlichen Teile des Hufes. Die Verbindung zwischen dem Kunstund Naturhorn ist inniger, als innerhalb der Naturhornmasse."

Durch den Beschlag mit dem Verbundhufeisen werden folgende Nachteile ausgeschlossen: Die Entstehung von Nagelkanälen mit der Gefahr aufsteigender Keimentwicklung und der eitrigen Lederhautentzündung sowie direkte oder indirekte Vernagelung mit einhergehender Schmerzauslösung und Lahmheit. Mit dem Verbundhufeisen vermeidet man die Einschränkung des Hufmechanismus, die Minderdurchblutung, die Drosselung des Blutrückflusses, Hornspaltenbildung und Tragrandausbrüche. Es kommt bei genetisch verminderter
Virginia B. Reef, Wendy E. Vaala, Leila T. Worth, Patricia L. Sertich, Pamela A. Spencer and Barbara Hammett (1995): Transabdominal ultrasonographic evaluation of the fetus and intrauterine environment in healthy mares during late gestation. Vet. Radiol. Ultrasound. 36, 533-541.

Virginia B. Reef, Wendy E. Vaala, Leila T. Worth, Patricia L. Sertich and Pamela A. Spencer (1996): Ultrasonographic assessment of fetal wellbeing during late gestation: development of an equine biophysical profile. Equine vet. J. 28, 200-208.

Johanna M. Reimer (1997): Use of transcutaneous ultrasonography in complicated latter-middle to late gestation pregnancies in the mare: 122 cases. 43rd Ann. AAEP Proceedings Vol.43, 259-261.

M.H.T. Troedsson, Catherine D. Renaudin, W.W. Zent and J.V Steiner (1997): Transrectal ultrasonography of the placenta in normal mares with pending abortion: a field study. 43rd Ann. AAEP Proceedings Vol.43, 256-258.

Andrew J. McGladdery

Beaufort Cottage Stables

High Street

Newmarket

Suffolk, CB8 8JS

UK

tel.: +441638663150

fax +4411638660157
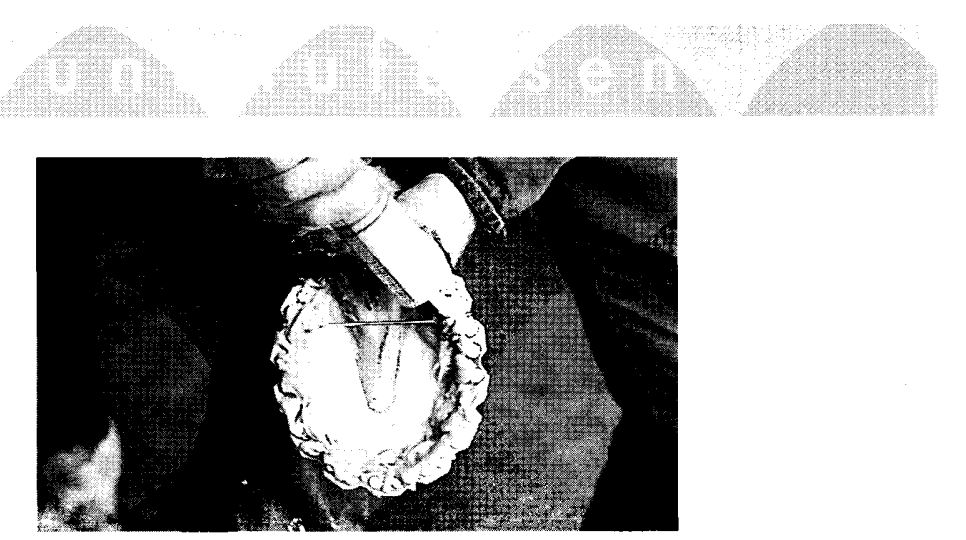

Hornqualität, zur Behandlung und Nachbehandlung von Hufrehe als Kunsthornbarriere gegen aufsteigende Keime und zur Korrektur von Hufimbalanzen zum Einsatz.

Weitere Einsatzgebiete sind: Podotrochlose-Syndrom, Beugesehnenprobleme, Sesambeinbänderveränderungen, Hornspalten, Hornklüfte, Chronische Rehe, untergeschobene, eingerollte Trachten, Hufbeinfraktur. Spat, Hufgeschwüre (Versiegelung nach tierärztlicher Behandlung), Hufknorpelverknöcherung.
Einhorn-Verbundhufeisen $\mathrm{GmbH}$
Hundestraße 62
23552 lübeck
Tel. (04 51) 7982968
Fax (04 51) 7982938 